\title{
Bashkir Verse from the Turkic Perspective
}

\section{Boris Orekhov*}

\begin{abstract}
The article discusses the statistically identified properties of Bashkir versification in comparison with the existing descriptions of other Turkic versification systems. The focus is on imparisyllabic forms, predominant meters, and peculiarities of rhyme. The study allows concluding that Bashkir Uzun-Kyuy (a regular alteration of 10- and 9-syllable lines) is unique and its equivalents are not found in other Turkic poetic traditions except the Tartar tradition, with which Bashkir verse has common roots. The frequency of Bashkir 9-syllable verse is also unusual as compared with poetry in other Turkic languages. Octosyllabic lines, which are often used together with 7-syllable verse, are common for various Turkic systems and can also be found in Bashkir poetry, most prominently in Kyska-Kyuy (a regular alteration of 8- and 7-syllable lines). More data is needed to judge to what extent the rhythm of Bashkir verse is comparable with the verse rhythm in other Turkic poetic traditions.
\end{abstract}

Keywords: Bashkir verse, Turkic versification, syllabic verse

\section{Introduction}

The Bashkir language belongs to the Turkic language family. Its speakers reside in the Volga region and Southern Urals in the Russian Federation. The number of speakers was estimated to be one million people in the 2010s, and the ethnic group itself is the title nation of a region within the Russian Federation, the Republic of Bashkortostan. The Bashkir language is cognate with the Tartar language; however, standard literary Bashkir has a number of peculiarities as to its phonetics and vocabulary. For example, such phonemes as /ð/ and / $\theta /$ are region-specific.

Active cultural and linguistic separation of the Bashkir people (cf. Anderson 1991) started after the Russian Revolution. Before the 1920s, the Bashkirs and Tartars had a common book culture based on the Volga Turki literary language.

Similarly to the Central Asian Turks (Uzbek, Turkmen, Kyrghyz, and other peoples), Bashkirs and Tartars have been dependent on the Arabic-Persian

* Author's address: Boris Orekhov, Faculty of Humanities, HSE University, 11 Pokrovsky Bulvar, Moscow 109028, Russia. E-mail: nevmenandr@gmail.com. 
cultural influence since the Middle Ages. This influence manifested itself in the borrowings of generic and stanzaic forms of traditional oriental poetics and in the formation of a very peculiar system of versification known as Turkic Aruz (Köprülü 1964). It penetrated into the Turkic world through Old Uzbek literature and represents a variant of Persian Aruz, i. e. a versification system based on a regular alternation of long and short syllables. This system was originally created for the Arabic language, but due to the Arab cultural expansion it gained wider circulation. Turkic Aruz is interesting because the Old Uzbek language from which this system was formed did not have a phonological opposition of long and short vowels. This remarkable fact refutes the idea endorsed by common sense that a versification system based on features not available in the language is impossible. The Turkic Aruz is based on several conventional assumptions: both a closed syllable and a syllable in a word of Persian origin that is long in the Persian language are considered "long" syllables.

However, in the 1920s the influence of Aruz on the developing Bashkir literature plummeted (Iskandarova 2013), and poetry switched to another form of versification, namely to syllabic verse. Aruz acquired a reputation of "reactionary" verse associated with the tsarist regime. Although different in pace, this process was parallel to the evolution of other Turkic literary forms that fell under Soviet influence. In the 1960s, Aruz was most commonly used in Azerbaijani poetry (Dzhafar 1968). The Bashkir versification system of the last century was syllable-based. The same principle (syllabics) was applied in folklore songs - the evidence thereof is found thanks to Polish Turkologist Tadeusz Kowalski (1921). He made notes from among the Kazan Tartars, but found no significant difference between Bashkir and Tartar verse. The same principle evidently applies in both folkloric and authorial poetry.

Furthermore, we compare the peculiarities of Bashkir versification with other Turkic traditions. There are two circumstances relevant to our study.

First, although not as intense as Russian verse studies, the study of Turkic verse continued to develop throughout the Soviet time. Viktor Zhirmunsky, a prominent scholar of Russian verse, who studied poetry in Turkic languages (Zhirmunsky 1964, 1968), utilized Russian verse theory utilized the frame of reference for his research, greatly influenced other researchers of Turkic versification systems. Starting from the 1950s, poetry scholars' systematic works made possible the description of versification trends in Kazakh, Uighur, Turkmen, Kyrghyz, Chuvash, Yakut, Tuvan, and other languages. A 1991 monograph retrospectively stated that "Turkic versification was mostly flourishing in the 1960s" (Toburokov 1991: 4). Therefore, we have the opportunity to compare the 
descriptions of Turkic verse systems made by twentieth-century Turkologists and what we observe in Bashkir verse.

Second, Bashkir verse has been thoroughly studied including within a reference manual on Bashkir verse (Khösäjenov 2003), a monograph chapter (Fazylova 2017: 98-120), and as subject of various research papers (Kaskinova 2007; Fajzullina 2010; Iskandarova 2013). Most recently, in 2019 a monograph was published in which the corpus and statistical methods developed in the studies of Russian poetry were used to describe the entire tradition of Bashkir syllabic verse (Orekhov 2019a).

The practice of linguistic typology more commonly made a comparison of incognate languages than comparison of the cognates, unless the aim was a historical reconstruction. Research sampling implicitly includes the idea that in closely related languages there are too many common elements which prevent us from seeing the diversity actually present in the world of languages. However, intragenetic typology is also often used in linguistics (Majid et al. 2007; Koptjevskaja-Tamm et al. 2010; Rakhilina, Reznikova 2013; Majid et al. 2015). Our aim is not to reconstruct proto-Turkic verse (an attempt was made in Korsh 1909). At the same time, as shown below, comparative Turkic metrics reveal a high level of distinctiveness of various Turkic verse systems.

\section{Imparisyllabic Forms in Turkic Syllabic Verse}

The key forms that specify the Bashkir versification system are Uzun-Kyuy (Bashkir: озон көц̆; Russian: узун-кюй) and Kyska-Kyиy (Bashkir: кысска көц̆; Russian: кыска-кюй). Both are imparisyllabic forms of folk origin (Orekhov 2019b) and are also found in Tartar folk songs (Smirnova 2010). Uzun-Kyuy, a regular alternation of 10- and 9-syllable lines (its name is translated as "drawling strains"), and Kyska-Kyuy, a regular alteration of 8- and 7-syllable lines ("short strains"), together cover about half the corpus of Bashkir poetry.

The scholarly wisdom is that isosyllabic text structures are typical of syllabic poetry. It seems so obvious that isosyllabism is sometimes equated with syllabic verse (Polivanov 1973: 105; Kholshevnikov 2004: 12). However, it has already been pointed out that compatibility and commensurability of certain lines does not mean their equality (see, for example, Iljushin 2004: 17). Let us observe these forms in Turkic verse systems. We shall move centrifugally from the poetic traditions that are culturally close to the Bashkir tradition to the more distant cultures. Therefore, we should first consider Central Asian Turks and then complement our observations with the material of Siberian 
Turkic cultures that were beyond the Arabian and Persian cultural influence. The commonality with the first group can be determined by direct interaction. As for the other group, however, the commonality can be explained through both the reflexes of the proto-Turkic forms and the typological parallels caused by the similarity of these languages.

As early as the 1960s, it was observed that "the principle of isosyllabism is not limited to the establishment of common commensurability of poetic lines" (Akhmetov 1964: 25). In Kazakh folklore, an alteration of 7- and 8-syllable lines was observed, i. e. the Kazakh equivalent of Bashkir Kyska-Kyuy. At the same time, in the 1970s, under the obvious influence of a simplistic understanding of syllabics, a step back was made, and Kazakh poetry scholars started to conjecture about strictly parisyllabic lines (Utesheva 1979: 10). It is not impossible that isosyllabic texts are more typical of authorial poetry, whereas imparisyllabic structures are characteristic of folk tradition.

Kyrghyz poetry also demonstrates a non-obligatory character of isosyllabic structures in syllabic verse (Rysaliev 1965: 38), and the alteration of 7- and 8-syllable lines is considered a meter (Rysaliev 1965: 45). Later, researchers following the example of the statistical study of Russian verse found regular meters in $90.48 \%$ of lines (Shapovalov 1986: 39). One of these meters is a combination of 7- and 8-syllable lines, which is quite common in Kyrghyz poetry and comprises $29.13 \%$ of lines (Shapovalov 1986: 41). Scholars have also identified 7- and 8-syllable lines in Uighur verse (Khamraev 1963: 107).

Scholars of Siberian Turkic versification often mention imparisyllabic lines as a common feature of syllabic verse. That said, Khakas authorial poetry has the same proportion of imparisyllabic and isosyllabic texts (Trojakov 1964: 34 ), and "an alteration of 7 - and 8-syllable in such lines is quite common" in Khakas poetry (Ungvitskaja 1952: 11). An alteration of 7- and 8-syllable lines is also found in Tuva folklore (Toguj-ool 1953; Dongak 1999: 6). However, the parisyllabic texts dominate and account for $90 \%$ of all the analyzed texts.

By the 1980 s, Yakut poetry has had $67 \%$ to $87 \%$ of texts written in "nearly isosyllabic" lines (Tobukorov 1985: 25). Correspondingly, other texts do not fall under this description and are considered imparisyllabic.

Therefore, imparisyllabism is an established feature of Turkic syllabics. At the same time, this feature is mostly exemplified by the texts, in which 7 - and 8 -syllable lines alternate. This poetic form is found in the native cultures of populations distanced from each other both geographically and culturally. Forms analogous to Kyska-Kyuy are found in Kazakh, Kyrghyz, Uighur, Khakas, and Tuvan poetic traditions. However, scholars never mention any form similar to Bashkir Uzun-Kyuy (a regular alteration of 10- and 9-syllablic lines), and it is highly likely that this form is specific to the Bashkir versification system. 


\section{Turkic Syllabic Verse Metrics}

The most frequent lines in Bashkir poetry have 9, 10, 8 and 7 syllables. Taken together, they comprise more than $80 \%$ of all lines in the corpus (Orekhov 2019a: 94-95). Among the leaders, the 9-syllable lines are most frequent (28.198\%). This situation is ensured by the widespread Uzun-Kyuy form and a significant number of isosyllabic poems.

It is worth saying that there has been no systematic calculation of the prevalence of particular line lengths in other Turkic traditions. Nevertheless, some Turkologists have described their literary experience and identified what they thought to be the most frequent meters.

In the 1950s, Chuvash poetry was predominantly written in 7-syllable lines (Ivanov 1958: 8). The semantics of this meter had social and national overtones because "the 7-syllable meter, which is also found in the folklore repertoire of all ethnic groups of the Chuvash people was a sui generis symbol of consolidation and the unity of the nation" (Rodionov 1992: 146). In general, the system of Chuvash verse is built on the opposition between short lines (7- or 8-syllable) and long lines (11-syllable) (Rodionov 1980: 13). It is remarkable that the lengths of 9 and 10 syllables, which are actively exploited in Bashkir poetry, are neither found in Chuvash versification, nor favoured in most of the other Turkic poetic systems.

Scholars claim that the lines of 6,8 and 11 syllables are the most widespread in Kazakh poetry (Utesheva 1979). The 11-syllable meter is considered the most typical for Kazakh verse (Akhmetov 1964). This situation is similar to that observed in Chuvash poetry with only one exception: in Kazakh, the shortest meter is hexasyllabic, and not heptasyllabic, as in Bashkir.

In the Kyrghyz system of versification, 7- and 11-syllable meters are predominant (Rysaliev 1965: 41, 50), whereas 8- and 9-syllable lines, never found in folklore, emerged in authorial poetry at a later stage (Rysaliev 1965: 46). Later studies revealed that 11 -syllable verse came into existence as late as the 1920s, while earlier Kyrghyz poetry was not familiar with this meter (Shapovalov1986: 32).

The following observations have been made about Azerbaijani verse: the 11-syllable meter is widespread in folklore (Aliev 1966); most lyric songs use 7-, 8- and 11-syllable lines (Aliev 1976: 12). Furthermore, in authorial poetry, 7-syllable lines are the most frequent (Allakhjarov 2011: 102).

In Turkmen verse, 11-syllable lines dominate (Redzhepov 1969: 57; Bekmuradov 1980:3), and the next most frequent meter is octosyllabic (Abdullaev 1983: 21). In the work of Turkmenistan's most important poet, Makhtumkuli, 
7-syllable meter is the third most frequent (Bekmuradov 1990: 38). A significant frequency of the 14-syllable meter is also specific to the Turkmen verse system.

For Uighur verse, 7-, 8- and 11-syllable meters are the most common (Khamraev 1963: 107), but in the 1980s, Uighur poetry witnessed an increase in the popularity of the 10-syllable meter (Khamraev 1988: 60), which is an infrequent guest in other Turkic poetic cultures except the Bashkir tradition.

The situation is somewhat different in the Siberian region. The most common Yakut meter is heptasyllabic (Vasilev 1965). In Altai poetry, in addition to the 7- and 8-syllable meters, the presence of the 9-, 10-, 11- and 12-syllable meters is also noticeable (Katashev 1972: 7). Such innovations as 13- and 14-syllable meters did not gain popularity (Ibid.). The most popular meter in the Tuvan poetry is octosyllabic. In different periods, it comprised from $32 \%$ to $75 \%$ of lines, while dodecasyllables comprised between $22 \%$ and $38 \%$ (Dongak 1999: 157).

Therefore, in comparison with Siberian Turks, the Turkic peoples greater influenced by the Arabic-Persian culture more actively use the 11-syllable meter, which is not very popular in Siberia. At the same time, dividing poetic traditions into those that prefer 7-syllables (Kyrghyz, Yakut) and those that prefer 8-syllables (Kazakh, Tuvan) has no regional basis. The majority (Chuvash, Turkmen, Altai poetries) actively use both 7- and 8-syllable lines together.

As we can see, the predominant use of 9-syllable meters in Bashkir verse is unique among Turkic versifications. In other Turkic traditions, this meter is either absent among the common meters or is less frequent than others (Altai, Kyrghyz). The same applies to the presence of 10-syllable meter among the predominant meters of Bashkir poetry. Decasyllables, to a certain extent, are noticeable (but are not the most frequent) only in Altai and Uighur versifications. As was already mentioned in the previous section, the high frequency of 9- and 10-syllable lines in Bashkir poetry is predetermined by the popularity of the Uzun-Kyuy form.

\section{Rhythmic Peculiarities}

The rhythm of Bashkir syllabic verse has some features that become visible to the researcher only through calculations. Whereas the meter of syllabic verse is its length calculated in syllables, its rhythm is determined by the structure of a line which consists of words of different lengths. The intuition that the words that make up a line are an important feature of Turkic syllabic verse is quite common. It is even expressed in the traditional terminology of Turkic 
poetics: turak, 'rhythmic group'; vazn (Arabic: wazn; Russian: вазн), 'a variant of the line with a certain configuration of word-boundaries' (Khamraev 1969).

One of the features of Bashkir rhythm is the basis for the hypothesis of parity counting (Orekhov 2019a: 136-139). A corpus-based statistical study has revealed that in Bashkir poetic texts even-syllable words are significantly more frequent than in prosaic texts. Furthermore, in the even-syllable lines, there are uneven distributions of forms that contain only even-syllable words and the forms that contain both even- and odd-syllable words: the even-syllable lines that contain odd-syllable words are significantly less frequent in the corpus. The most frequent forms of even-syllable lines consist only of even-syllable words. The probability of the occurrence of a two-syllable word in the initial position in a line is roughly equal to the probability of its occurrence in a poetic text in general, but the probability of the occurrence of a three-syllable word at the beginning of a line is lower than the probability of the occurrence of a three-syllable word in a text. Two odd-length words in a line usually follow one another, thus forming even-length aggregate blocks. That said, the distribution of odd-syllable words is not random, and a distant placement of two odd-length words is very rare.

The hypothesis of parity counting claims that, when constructing a line of poetry, a Bashkir poet uses, first of all, words of even lengths ( 2 and 4 syllables). And, that only in the odd-syllable lines (7-, 9-, and 11-syllable lines), are odd-syllable words added at the very end, when the basic structure of the line has already been formed.

The preference of even numbers over odd numbers by the human perception mechanisms is well known in psychology. In 1990, the so-called odd effect was discovered (Hines 1990): participants would find it harder to decide if they are dealing with an even or odd number if the number was odd. Furthermore, participants would find it harder to identify the class of the number if the number is odd. Hines suggested the reason for that effect was a linguistic compound of the experiment because participants had to identify even and odd numbers using the words even and odd which, in English (the mother tongue of the participants), are charged with other meanings and additional associations. However, later there were other studies that gave a different explanation of this phenomenon (Nuerk et al. 2004).

In general, psychologists are inclined to state that the reason lies in the linguistic markedness of response codes (MARC) rather than in the quantity itself, as was also demonstrated through trials (Huber et al. 2014). But, perhaps, there is also a class of counting problems with which it is more convenient to cope with even numbers our cognitive mechanisms. The fundamental difference between 
even and odd numbers was much talked about during the study of brain asymmetry, projecting open effects on the mechanisms of culture (Ivanov 1978).

It is not known if we can extrapolate the hypothesis of parity counting to other Turkic syllabic traditions. Certain observations made by Turkologists speak to a greater extent in favor of the fact that we are dealing with a unique feature of Bashkir verse.

A Turkmen poetic text consists mainly of monosyllabic and disyllabic words. Three-syllable and four-syllable words rarely appear in poetry and are mainly verb forms, which, according to the researcher, "are of little use in the language of poetry and song" (Redzhepov 1969: 56). In ancient times, the 11-syllable verse was canonized in form $2+2+3+2+2$ (each digit denotes a word of the corresponding length in syllables), but other representations of it became possible over time, i.e. $4+3+4,4+4+3,3+4+4$ or $3+3+3+2$ (Redzhepov 1969: 58). Thus, in Turkmen verse, there is no significant difference between words of even and odd length, as well as between the meter of a line ending in words of even and odd length.

A review of the verse material of the Turkic peoples of Siberia (Toburokov 1991) also does not show those pronounced signs that Bashkir verse demonstrates. But Tuvan data still illustrate the predominance of four-syllable over three-syllable words (Dongak 1999: 69), which is not characteristic of the Altai and Khakas texts (Toburokov 1985: 93). At the same time, in Yakut poetry, "the three-syllable lexical unit is, as it were, the main rhythmic unit of the Oyunsky syllabic verse" (Vasil'ev 1965: 85).

The rhythm of the 9-syllable meter in Bashkir verse has a special property that we have christened Bolotov's rule. The Moscow linguist Sergey Bolotov was first to discover this pattern in the Bashkir material and during the discussion of my paper shared his finding: in the absolute majority of 9-syllable lines we find a mandatory word-boundary after the 6th syllable, that is, a 9-syllable verse has a line ending " +3 " or “ $+1+2$ " or “ $+2+1$ ", where the number is the syllabic length of the word(s) at the end of the line. This statement is true for $95.65 \%$ of all 9 -syllable lines. The most frequent rhythmic schemes of a 9-syllable line in the Bashkir versification are the following:

$2+2+2+3$ (Һанап без̧зең аккан вакытты... ['Counting our time elapsed...'], Шамил Анак, “Таштар менән һөйләшеү”), 27.26\% of all 9-syllable lines;

$4+2+3$ (Юлдаштары бала садымдың... ['Satellites of my childhood...'], Рәми Ғарипов, “Таныш күгәрсендәр”), 17.78\%; 
$1+3+2+3$ (Һин Ленинга биргән антыңдыл... ['A promise that you gave to Lenin...'], Рәми Ғарипов “Мәңге бергә”), 10.48\%.

Similar observations have been exemplified by the Kazakh material. Abay (1845-1904), canonized as a classical author of Kazakh poetry, used a rhythmic version of the 11-syllable meter with a 4-syllable ending. In the Soviet era, another version of this meter came into use with an ending in three syllables (Akhmetov 1964: 312). This observation allows us to conclude that the syllabic length of the line ending is an important feature of verse for the bearers of the tradition. At the same time, it is necessary to emphasize that this is not a complete structural analog of the clausula in European versification systems. The Turkic line ending cannot be described as a chain of syllables after the last stressed syllable: in Turkic languages, the dynamic accent is very weak and almost always falls on the last syllable.

\section{Conclusion}

Scholars of Turkic verse provided ample descriptions of their data. Although the Turkologists tend to avoid statistical methods, their studies make it possible to trace both common and distinctive features of Turkic meters and, partially, rhythms.

The most productive approach is to compare a complete statistical description of Bashkir verse with other Turkic versification systems to single out the unique features of the Bashkir system - in particular, the use of Uzun-Kyuy, a regular alteration of 10- and 9-syllable lines. Unlike another traditional Bashkir form, Kyska-Kyuy (a regular alteration of 8- and 7-syllabic lines), which is active in other Turkic traditions, Uzun-Kyuy is not typical to Turkic verse. In the broader context of typology, it is also uncommon for syllabics to use such an alteration, since syllabic verse usually shows preference toward isosyllabic structures.

The domination of Uzun-Kyuy results in the highest proportion of 9-syllable lines among lines of varied syllabic lengths. In Turkic verse systems, lines of this length are rarely found among the frequently used meters, and it is not predominant in any of the traditions described above. On the contrary, 11-syllable lines more commonly found in other Turkic systems are rather rare in Bashkir poetry.

Academic description of Turkic verse rhythm is still at an embryonic stage; progress in this field awaits both empirical and theoretical advances. However, 
we can already confirm that such features of Bashkir verse as parity counting and Bolotov's rule are either not prominent or perhaps even completely absent in other Turkic traditions. ${ }^{1}$

\section{References}

Abdullaev, Dovran 1983. Narodnye osnovy stikhoslozhenija v poezii Makhtumkuli. Ashkhabad: Ylym.

Akhmetov, Zakij Akhmetovich 1964. Kazakhskoe stikhoslozhenie (Problemy razvitija stikha $v$ dorevoljutsionnoj i sovremennoj poezii). Alma-Ata: Nauka.

Allakhjarov, Kamil Gusejnovich 2011. Genezis, stanovlenie i puti evoljutsii arzerbajdzhanskogo stikhoslozhenija. Kirov: Izdatel'stvo VjatGGU.

Aliev, Sabir Halil 1966. Formy klassicheskoj azerbajdzhanskoj poezii. Candidate (Ph.D.) dissertation, synopsis. Baku.

Aliev, Magomed Iradzh ogly 1976. Formy $i$ vidy azerbajdzhanskoj narodnoj poezii. Candidate (Ph.D.) dissertation, synopsis. Baku.

Anderson, Benedict 1991. Imagined Communities: Reflections on the Origin and Spread of Nationalism. Revised and extended edition. London, New York: Verso.

Bekmuradov, Akhmet 1980. Osnovnye tendentsii razvitija stikhoslozhenija $v$ turkmenskoj sovetskoj poezii. Candidate (Ph.D.) dissertation, synopsis. Ashkhabad.

Bekmuradov, Ahmet 1990. Poeticheskoe masterstvo Mahtumkuli Fragi. Doctoral dissertation, synopsis. Ashkhabad.

Dzhafar, Akrem 1968. Teoreticheskie osnovy aruza i azerbajdzhanskij aruz (v sravnenii s arabskim, persidskim, tadzhikskim, turetskim i uzbekskim aruzami). Doctoral dissertation, synopsis. Baku: Izdatel'stvo Akademii nauk Azerbajdzhanskoj SSR.

Dongak, Uran Aldyn-oolovna 1999. Tuvinskoe stikhoslozhenie. Candidate (Ph.D.) dissertation. Kyzyl.

Fajzullina, Ajgul' Bilalovna 2010. Traditsii vostochnoj literatury v bashkirskoj poezii XIX - nachala XX veka. Candidate (Ph.D.) dissertation, synopsis. Ufa.

1 The work has been supported by the Ministry of Science and Higher Education of the Russian Federation within Agreement No 075-15-2020-793. 
Fazylova, Florida Salimovna 2017. Nravstvenno-eticheskie problemy v sovremennoj bashkirskoj poezii (II polovina XX - nachalo XXI veka). Ufa: Bashkirskaja entsiklopedija.

Hines, Terence M. 1990. An odd effect: lengthened reaction times for judgments about odd digits. In: Memory \& Cognition 18, 40-46. https://doi.org/10.3758/BF03202644

Huber, Stefan et al 2014. Embodied markedness of parity? Examining handedness effects on parity judgments In: Psychological Research 79 (6), 963-977. https://doi.org/10.1007/s00426-014-0626-9

Ivanov, Nikolaj Ivanovich 1958. Chuvashskoe stikhoslozhenie i ego osobennosti. Candidate (Ph.D.) dissertation, synopsis. Cheboksary.

Ivanov, Vyacheslav Vsevolodovich 1978. Chet i nechet: asimmetrija mozga i znakovykh sistem. Moskva: Sovetskoe radio.

Iljushin, Aleksandr Anatol'evich 2004. Russkoe stikhoslozhenie. Moskva: Vysshaja shkola.

Iskandarova, Svetlana Ajratovna 2013. Evoljutsija metricheskogo i sillabicheskogo stikhoslozhenija v bashkirskoj poezii nachala XX veka. Candidate (Ph.D.) dissertation, synopsis. Ufa.

Kaskinova, Gul'nur Nurimanovna 2007. Voprosy strukturnoj poetiki v sovremennoj bashkirskoj poezii. Candidate (Ph.D.) dissertation, synopsis. Ufa.

Katashev, Stepan Mihajlovich 1972. Osnovy altajskogo stikhoslozhenija. Candidate (Ph.D.) dissertation, synopsis. Moskva.

Khamraev, Maratbek Karimovich 1963. Osnovy tjurkskogo stikhoslozhenija ( $\mathrm{Na}$ materiale ujgurskoj klassicheskoj i sovremennoj pojezii). Alma-Ata: Izdatel'stvo Akademii Nauk Kazakhskoj SSR.

Khamraev, Maratbek Karimovich 1988. Plamja zhizni (o sisteme stikhoslozhenija tjurkojazychnykh narodov). Tashkent: Izdatel'stvo literatury i iskusstva imeni Gafura Guljama.

Kholshevnikov, Vladislav Evgen'evich 2004. Osnovy stikhovedenija: Russkoe stihoslozhenie. Sankt-Peterburg: Filologicheskij fakul'tet SPbGU; Moskva: Izdatel'skij centr "Akademija”.

Khösäjenov, Ghajsa 2003. Bashqort shighyry. Shighriät 囚üźlege. Ufa: Ghilem.

Koptjevskaja-Tamm, Maria; Divjak, Dagmar; Rakhilina, Ekaterina Vladimirovna 2010. Aquamotion verbs in Slavic and Germanic: A case study in lexical typology. In: Victoria Hasko, Renee Perelmutter (eds.). New Approaches to Slavic Verbs of Motion (Studies in Language Companion Series 115). Amsterdam, Philadelphia: John Benjamins, 315-341. https://doi.org/10.1075/slcs.115.18kop 
Korsh, Fedor 1909. Drevnejshij narodnyj stikh turetskikh plemen. In: Zapiski Vostochnago otdelenija Imperatorskago russkogo arhologicheskago obshchestva 19(2/3), 139-167.

Kowalski, Tadeusz 1921. Ze studiów nad forma poezji ludów tureckich. Krakow: Nakł. Polskiej Akademji Umiejętności.

Köprülü, Mehmet Fuad. 1964. La metrique 'arūż dans la poesie turque. In: Philologiae Turcicae Fundamenta II. Wiesbaden: Franz Steiner, 252-266.

Majid, Asifa; Gullberg, Marianne; van Staden, Miriam; Bowerman, Melissa 2007. How similar are semantic categories in closely related languages? A comparison of cutting and breaking in four Germanic languages. In: Cognitive Linguistics 18(2), 179-194. https://doi.org/10.1515/COG.2007.007

Majid, Asifa; Jordan, Fiona; Dunn, Michael 2015. Semantic systems in closely related languages. In: Language Sciences 49, 1-18. https://doi.org/10.1016/j.langsci.2014.11.002

Nuerk, Hans-Christoph; Iversen, Wiebke; Willmes Klaus 2004. Notational modulation of the SNARC and the MARC (linguistic markedness of response codes) effect. In: The Quarterly Journal of Experimental Psychology. Section A: Human Experimental Psychology 57(5), 835-863. https://doi.org/10.1080/02724980343000512

Orekhov, Boris 2019a. Bashkirskij stikh XX veka. Korpusnoe issledovanie. SanktPeterburg: Aleteija.

Orekhov, Boris 2019b. Metr otrezkov dlinnee stroki v bashkirskom sillabicheskom stikhe. In: Izvestija Rossijskoj akademii nauk. Serija literatury i jazyka 78(2), 41-50.

Polivanov, Evgenij Dmitrievich 1973. O prieme alliteratsii v kirgizskoj pojezii v svjazi s poeticheskoj tekhnikoj i jazykovymi faktorami drugih "altajskih" narodnostej. In: Problemy vostochnogo stikhoslozhenija. Moskva: Nauka. Glavnaja redaktsija vostochnoj literatury, 100-106.

Rakhilina, Ekaterina Vladimirovna; Reznikova, Tatjana Isidorovna 2013. Frejmovyj podkhod k leksicheskoj tipologii. In: Voprosy jazykoznanija 2, 3-31.

Redzhepov, Rahman 1969. Liricheskoe soderzhanie i iskusstvo stikha. Doctoral dissertation, synopsis. Ashkhabad.

Rodionov, Vitalij Grigor'evich 1980. Chuvashskoe i tjurkskoe stikhoslozhenie: Uchebnoe posobie. Cheboksary: Izdatel'stvo Chuvashskogo universiteta.

Rodionov, Vitalij Grigor'evich 1992. Chuvashskij stikh. Problemy stanovlenija i razvitija. Cheboksary: Chuvashskoe knizhnoe izdatel'stvo. 
Rysaliev, Kulan 1965. Kirgizskoe stikhoslozhenie. Doctoral dissertation, synopsis. Frunze.

Shapovalov, Vjacheslav Ivanovich 1986. Kirgizskaja stihotvornaja kul'tura i problemy perevoda. Frunze: Kyrgyzstan.

Smirnova, Elena Mikhajlovna 2010. Ritmicheskij stroj muzykal’no-poeticheskogo fol'klora tatar-musul'man Volgo-Ural'ja. Doctoral dissertation, synopsis. SanktPeterburg.

Toburokov, Nikolaj Nikolaevich 1985. Jakutskij stikh. Yakutsk: Jakutskoe knizhnoe izdatel'stvo.

Toburokov, Nikolaj Nikolaevich 1991. Problemy sravnitel'nogo stikhovedenija (na materiale sovetskoj poezii tjurkojazychnyh narodov Sibiri). Yakutsk: Nauka.

Toguj-ool, Akeksandr S. 1953. Opyt issledovanija tuvinskogo stikhoslozhenija. In: Uchenye zapiski Tuvinskogo nauchno-issledovatel'skogo instituta jazyka, literatury $i$ istorii 1. Kyzyl: Tuvinskoe knizhnoe izdatel'stvo, 93-110.

Trojakov, Petr Anisimovich 1964. K voprosu o khakasskom stikhoslozhenii. In: Uchenye zapiski Khakasskogo nauchno-issledovatel'skogo instituta jazyka, literatury $i$ istorii. Serija fol'kloristiki 10. Abakan: Krasnojarskoe knizhnoe izdatel'vo, Khakasskoe otdelenie, 26-43.

Ungvitskaja, Marija Andreevna 1952. Khakasskoe stikhoslozhenie. Candidate (Ph.D.) dissertation, synopsis. Moskva.

Ungvitskaja, Marija Andreevna 1955. K voprosu o hakasskom stihoslozhenii. In: Uchenye zapiski Abakanskogo gosudarstvennogo pedagogicheskogo instituta 1. Abakan, 130-143.

Utesheva, Evgenija Adilovna 1979. Ritmiko-intonacionnaja struktura kazakhskogo liricheskogo stikha (eksperimental'no-foneticheskoe issledovanie). Candidate (Ph.D.) dissertation, synopsis. Alma-Ata.

Vasilev, Georgij Mitrofanovich 1965. Jakutskoe stikhoslozhenie. Yakutsk: Jakutskoe knizhnoe izdatel'stvo.

Zhirmunskij, Viktor Maksimovich 1964. Ritmiko-semanticheskij parallelizm kak osnova drevnetjurkskogo narodnogo epicheskogo stikha In: Voprosy jazykoznanija 4, 3-24.

Zhirmunskij, Viktor Maksimovich 1968. O nekotoryh problemakh teorii tjurkskogo narodnogo stikha. In: Voprosy jazykoznanija 1, 23-42. 